\title{
DECODING THE SMART CITY NARRATIVE
}

\author{
by \\ Desislava Boynska-Nikolova \\ Bachelor of Science, Computer Science, Mathematics \\ State University of New York College at Brockport, 2005
}

\author{
An MRP \\ presented to Ryerson University \\ in partial fulfilment of the \\ requirements for the degree of \\ Master of Digital Media \\ in the program of \\ Digital Media
}

Toronto, Ontario, Canada, 2017

(C) Desislava Boynska-Nikolova, 2017 


\section{AUTHOR'S DECLARATION}

I hereby declare that I am the sole author of this MRP. This is a true copy of the MRP, including any required final revisions. I authorize Ryerson University to lend this MRP to other institutions or individuals for the purpose of scholarly research. I further authorize Ryerson University to reproduce this MRP by photocopying or by other means, in total or in part, at the request of other institutions or individuals for the purpose of scholarly research. I understand that my MRP may be made electronically available to the public. 
ABSTRACT

\title{
DECODING THE SMART CITY NARRATIVE
}

\author{
Master of Digital Media, 2017 \\ Desislava Boynska-Nikolova \\ Master of Digital Media, Ryerson University
}

It is a common misconception that smart cities are simply those that use Information and Communication Technologies. In fact, it is not as straightforward as that. A wide range of definitions exists out there regarding the smart city concept. While they do have in common an innovative and creative approach to solving urban problems, they also differ in the extent, reach, method, goals, and strategies utilized to fulfil those definitions.

The author of this paper examined over 50 definitions from various contexts and identified a common, but also inherently diverse, set of goals smart cities claimed to represent. They also vastly diverged in their strategies and time lines. From brand new cities designed to be smart to smart initiatives of varying complexity, there is no single and agreed-upon definition among the various stakeholders. This paper attempts to decode the smart city narrative that has been over two decades in the making. 


\section{DEDICATION}

I would like to dedicate this research with all my love to my late Dad who always believed in me, and to my sons Kristian Asen and Oliver George who are my world. 


\section{Table of Contents}

AUTHOR'S DECLARATION......................................................................................

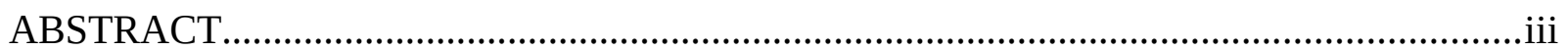

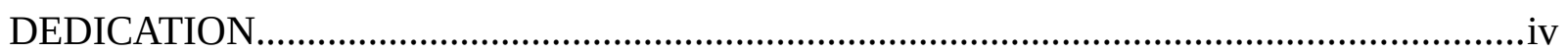

LIST OF APPENDICES.........................................................................................

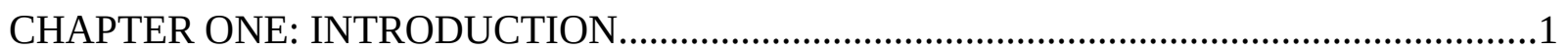

Background and Motivation...................................................................................

Research Goals and Objectives............................................................................2

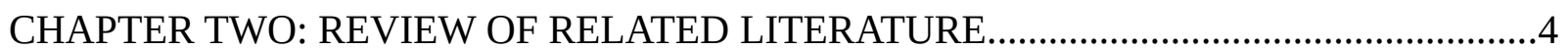

CHAPTER THREE: METHODOLOGY AND RESEARCH DESIGN................................

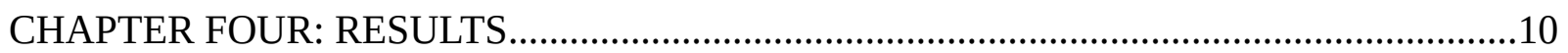

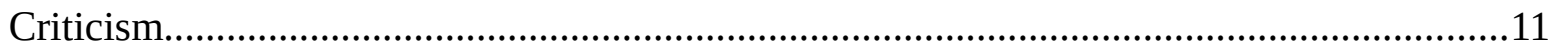

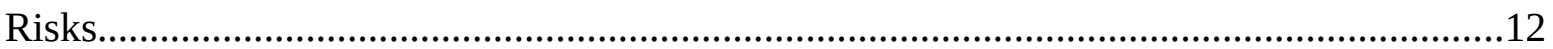

CHAPTER FIVE: SUMMARY, CONCLUSIONS, AND RECOMMENDATIONS...............14

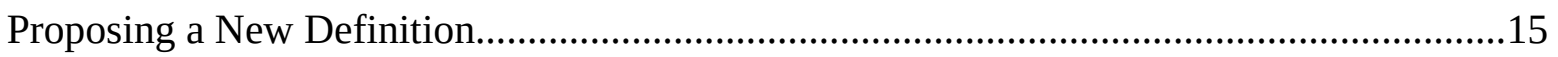

Appendix A: Smart City Definitions by Cities..............................................................17

Appendix B: Smart City Definitions from the Public Sector..............................................22

Appendix C: Smart City Definitions from the Private Sector...........................................24

Appendix D: Smart City Definitions in the Media..........................................................26

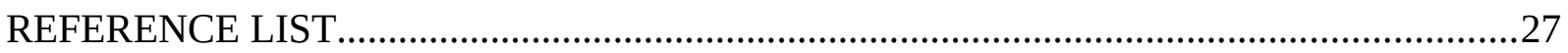




\section{LIST OF APPENDICES}

Appendix A: Smart City Definitions by Cities

Appendix B: Smart City Definitions from the Public Sector

Appendix C: Smart City Definitions from the Private Sector

Appendix D: Smart City Definitions in the Media 


\section{CHAPTER ONE: INTRODUCTION}

\section{Background and Motivation}

The world's population reached almost 7.6 billion in mid-2017, which is an increase of one billion over a period of 12 years, and an increase of two billion since 1993 (World Population Progress Revision, 2017). The UN projects that the world population will reach 8.5 billion by 2030, 9.7 billion by 2050 and 11.2 billion by 2100 (World Population Prospects: The 2015 Revision). In 2017, urban population represented 54 percent of the world's population and is expected to grow to 70 percent in 2050. (Albino, Berardi, \& Dangelico, 2015).

Cities attract people with more and better social and economic opportunities, but as global urbanization continues to rise, so does the environmental strain. Guzmán (2015). Glasmeier and Christopherson (2015) argued, “This will pose serious challenges for city planners, who will have to [rethink] how they provide basic city services to residents in a sustainable manner." Smart City Expo World Congress 2016 accented the idea that the cities of the future will be those that actively engage their citizens in the crafting of progress and improvements, rather than simply accepting those advancements. It also acknowledged that technology is giving rise to "a new kind of urban growth - one that is more efficient, transparent and sustainable, disrupting the form and function of our cities." (Smart City Expo World Congress 2016).

The smart city concept has been around for over two decades to help cities search for creative solutions to their pressing challenges, but there has not been a general consensus as to what smart city actually means. Broad and vague smart city definitions have been abundant in all spheres of life, each applying a different connotation to a malleable concept. 
Technology and citizen involvement are transforming the urban scene in novel ways and much faster than ever before, which opens up a lucrative industry segment. The branding aspect of a smart city is strong as it gives leverage to increase prestige and other ratings that make cities appealing. According to Glasmeier and Christopherson (2015), the global smart city market will be valued at US $\$ 1.565$ trillion by 2020 . However, investments in smart cities may be risky if the providers and recipients of smart city services and solutions do not share the same understanding and expectations from a smart city, and the goals it can help accomplish.

\section{Research Goals and Objectives}

The race towards incorporating digital technologies into the governing and support of urban areas around the world has blurred the term "smart city". Cities are sometimes described as systems of systems. Like living organisms, they continuously change, either adapting or decaying. Similarly, the smart city notion has been changing and evolving to encompass a wider spectrum of initiatives, aspects of urban life, and levels of involvement. With that, a richer selection of terms has sprouted to complement, or possibly to distinguish from, the smart city narrative - smart city, digital city, intelligent city, information city, responsive city, sustainable city, resilient city, low-carbon city, eco-city, liveable city, ubiquitous city, flex city, virtual city, and even cyberville. As people adapt to a new reality of ubiquitous technology, they begin to expect more out of their cities and governments, too. As technology itself continues to evolve, the concept of smart city transforms to incorporate those advances. With the maturing of the smart city notion, creative solutions originating in diverse fields (not only digital technology) begin to take shape. 
The purpose of this paper was to answer the questions, "What is a Smart City"? Is it one that uses Information and Communication Technology? Is it a city that is sustainable and ecofriendly? Is it one that is home to universities and/or technology companies? Is a smart city innovation-focused? Or connected? Or interactive? Or all of the above?

This study examined smart city definitions from different contexts including the public sector, the private sector, academia, and media. The paper explored smart city definitions of existing cities from all continents, as well as smart city strategies, new smart city developments, and the various "smart" projects and initiatives deployed by urban centres, and identified the recurring parameters in those definitions. Despite the geographical, economic, political, cultural, and historical differences of cities, what are the common denominators? Through the analysis of these smart city definitions, as well as the historical evolution of the term, the paper tried to decode the smart city narrative, and put forth a new definition that attempts to structure the fluid concept into meaningful consistency in a general, yet constrained way. 


\section{CHAPTER TWO: REVIEW OF RELATED LITERATURE}

Glasmeier and Christopherson (2015) observed that "[...] ambitious politicians and civil servants are ever on the search for the next 'big idea' to move their city to the top of the rank of attractive places. The race to get on the bandwagon and become a smart city has encouraged city policymakers to endogenise the process of technology-led growth, directing municipal budgets toward investments that bestow smart city status." Smart city is commonly understood as one that employs Information and Communications Technology into all of its functions, including government, services, environment, transport, social infrastructure, energy, and buildings (Abdoullaev, 2011). Karl (2015) agreed with that description by explaining, "The idea of the 'smart city' has emerged in this context as a way for cities to differentiate themselves by investing in technological and information management systems to enhance urban livability." Sadiku et al. expand the notion to include "investments in human and social capital, transport and ICT fuel sustainable economic growth and a high quality of life, with a wise management of natural resources, through participative governance". Some smart city definitions are broad and somewhat vague, such as the one by Branchi, Matias, and Fernandez-Valdivielso (2014), “A space for coexistence among people who, based on the available technologies, can thrive and develop, while taking into account economic, social and environmental sustainability.”

Because of the complexity of the urban narrative in general, many studies offer lengthy and all-encompassing descriptions. "A smart city is a high-tech urban area that connects people, information[,] and technologies in order to increase life quality. Smart cities are those communities that pursue sustainable economic development through investments in human and social capital and manage natural resources through participatory policies. A smart city monitors the conditions and integrates critical infrastructures such as bridges, tunnels, roads, subways, 
airports, seaports, and buildings. Components of a smart city include smart people, smart governance, smart homes, smart infrastructure, smart technology, smart economy, smart mobility, smart living, smart parking, and smart environment." (Sadiku et al., 2016).

Robinson (2015) observed that the basic dilemma regarding smart cities is whether "smart" refers to digital technology, or simply to any creative resource manipulation. Bird (2015) argued, "A smart future for our cities is not just one where information and communication technologies (ICTs) reign; it is one where the use of ICTs creates new services for citizens, enhances or replaces infrastructure and improves economic growth. This "citizen-centric" approach will change how the urban dweller moves, thinks, cooperates and works in ways that will be smart, very smart indeed."

A difficult to explain concept may be easier to portray in terms of what it is not. Abdoullaev (2011) proposed, "A Smart City is NOT one with at least one initiative addressing one or more of the following six characteristics: Smart Governance, Smart People, Smart Living, Smart Mobility, Smart Economy and Smart Environment. A Smart City is NOT city seeking to address public issues via ICT-based solutions on the basis of a multi-stakeholder, municipally based partnership. A truly smart city is three innovative cities in one, the Urban Trinity of Information Cyber City, Intelligent/Knowledge City[,] and Ecological/Clean city. It is essential to draw distinctions between a smart city, as a unified urban entity, and "smart city" technologies, applications, and systems, as well as fragmented "smart city" projects, lacking the overall conception of the smart city project and resulting in unsustainably over-costly ventures."

Glasmeier \& Christopherson (2015) research illustrated the aspects of smart cities that academics, philanthropists, and large information companies find appealing, "Academics are attracted to technology applications that offer the ability to 'sense' and track human use of urban 
infrastructure. [...] Philanthropists see solutions to urban ills with an eye toward greater equity, improved quality of life and citizen empowerment. The large information firms see the vastly expanding market for management applications in an urbanising world as an opportunity to develop stable revenue streams in the form of continuous contracts. These firms are, however, selling different visions of 'smart' and products to achieve the vision. Competing and sometimes contradictory stakeholder goals contribute to the inevitable conclusion that the smart city is a chaotic concept."

According to the ISO Technical Management Board's Strategic Advisory Group on Smart Cities, a smart city "[...] increases the pace at which it improves social, economic and environmental sustainability outcomes, responding to challenges such as climate change, rapid population growth and political and economic instability by improving how it engages with society, how it applies collaborative leadership methods, how it works across disciplines and city systems, and how it uses data information and modern technologies in order to provide better services and quality of life to those in, and involved with, the city, now and for the foreseeable future, without unfair disadvantage to others or degradation of the natural environment" (Bird, 2015). 


\section{CHAPTER THREE: METHODOLOGY AND RESEARCH DESIGN}

This paper studied 53 smart city definitions in the context of government, industry, academia and the media in an attempt to find the common denominators that constitute the smart city phenomenon from a 2017 point of view.

To discover a common ground in the "smart city" definition of each city, this paper reviewed the official websites of many of the top 100 cities on the Cities in Motion Index. These are cities that have already been named smart cities or have been executing smart initiatives in their urban planning, development, and management. These cities are located all over the world, on all continents, and vary in their ethnicity, languages, religions, and forms of government. 23 smart city definitions were obtained directly from those cities' websites. Through the review of academic literature, tech company websites, governmental institutions, and media were obtained another 30 definitions for the concept of smart city. The definitions or statements were compiled and analyzed - semantically and through a text analyzer tool (http://textalyser.net/index.php? lang=en\#analysis)- to identify the most commonly occurring words and phrases.

In the course of the research, the author discovered that many so-called smart cities that appeared on various smart city lists did not offer a formal definition, or even clearly described what their vision or strategy was. The majority of cities ran some form of smart projects and advertised their use of smart technologies without explaining to their citizens, partners or vendors what they meant by "smart".

To balance the generally positive sentiment towards smart cities, this research paper offers some critiques of the concept and attempts to gain insight into the marketing aspect of smart city branding. 
The complexity of any city arises from the numerous stakeholders involved, multiple characteristics, and the relationships between them. Smart city parameters include transportation, energy, education, healthcare, buildings, physical infrastructure, food, public safety, water quality and supply, energy supply, public transport, security, disaster resilience, wellness and proactive disease control, breathability of air, waste management, hours of quality rest time, transport efficiency, road safety, climate compatibility, carbon neutrality, urban-rural interface, technology horizon, comprehensive design, quantitative optimization, approach, and strategy. The key dimensions are smart economy, smart mobility, smart environment, smart people, smart living, and smart governance. The major differentiators between the various smart cities around the world are the goals they hope to achieve through their smart city plans.

A variety of rankings, indicators, and indexes have been used in an attempt to measure and compare the performance of smart cities around the world. Those include the Global City Indicators Facility, Mercer Quality of Living Survey, Green City Index, IEEE Core Smart Cities program, innovation ranking, and digital city ranking. ISO/TS 37151 measures the performance of community infrastructure and defines smart community infrastructures as those that largescale systems (such as transportation, water, sanitation) optimize to be sustainable and enhance quality of life (Lazarte, 2015).

Cities from all parts of the world have adopted the idea of the smart city. Existing cities on all continents, as well as brand new cities designed with the smart city concept in mind from the ground up tell their smart city story in unique ways. The smart city narrative is rich and colourful. Appendix A reveals the smart city definitions by the studied cities themselves. They differ from smart city projects being planned or deployed in many more cities around the world, because they attempt to be more comprehensive. Innovative urban initiatives include Madrid's 
smart waste management, Moscow's city as a service platform, and Helsinki's smart district

Kalasatama which combines renewable energy, Smart Grid technology, electric cars and smart traffic solutions. (Kalasatama, n.d.). 


\section{CHAPTER FOUR: RESULTS}

For the purposes of this research paper, 53 smart city definitions were obtained, and can be found in Appendix A (Smart City Definitions by Cities), Appendix B (Smart City Definitions from the Public Sector), Appendix C (Smart City Definitions from the Private Sector), and Appendix D (Smart City Definitions in the Media). The only word that appeared in more than half of the studied definitions, with the exception of "smart" or "city", was the word "technology" ("technologies", "technological"). It showed up in $66 \%$ of the definitions. "Economic" appeared 38\% of the time, "social" 34\%, and "quality of life" $26 \%$. One in four descriptions used "innovation" or "sustainability", and $21 \%$ of them talked about "efficiency".

The definitions mentioned citizens, inhabitants, people, residents, community/communities, and generations. They talked about competitiveness, efficiency, growth, innovation, connectivity, liveability (life, lives, living), sustainability, ecology, environment, economy, and culture. The following verbs appeared: address, use, change, understand, fuel, promote, deliver, create, increase, improve/improving, enhance/enhancing, ensuring, achieving, transforming, and supporting. They used adjectives such as resilient, responsible, intelligent, inclusive, and involved. They incorporated words such as new, better, future, advantage, opportunities, prosperity, quality, revolution, management, development, investments, concept, ideas, objective, technological and outcome. They included references to internet of things, ICT/Information and Communication/s Technology/Technologies, systems, networks, smart solutions, sensors, and devices. They referred to: wireless, natural resources, infrastructure, power, transport, utilities, services, energy, data, carbon, challenge/s, and consumption. Other words that appeared in those definitions were: business, government, human capital, science, social, creative, and digital. 
The only aspect of the term's definition that everyone agrees on is that there is no real consensus and that its meaning continues to change as the maturity, nature, and availability of technology evolves as well. The fluidity of what is meant by a smart city is enhanced due to the complexity of government at the municipal level, the variety of stakeholders involved, and the party expressing an interest in a smart city strategy or solution.

\section{Criticism}

Criticism of smart cities revolves around the argument that technology is becoming an end in itself as cities rush to join the constantly changing trend (Branchi et al., 2014). A major issue with the varied interpretations of the term and concept of a smart city is that if there is no common understanding as to what it is. Then how can we be sure we are expecting, or even paying for, the same things? Due to the lack of a consistent and undisputed definition, the term smart city becomes susceptible to distortion, renegotiation, and even mystification, affirming any new suggestion or interpretation. It becomes unpredictable and therefore even dangerous.

According to Robinson (2015), the increasing interest in smart cities comes with the reversal of a suburbanization trend from the last decades, the realization of the threats we are facing as climate changes, and the hope that cities, rather than national governments, armed with ubiquitous technology can solve those challenges. How can the concept be conveyed to every citizen in plain language and convincingly so that the inherent complexity of the building and management of a city is removed in order to highlight the improvements that a city aims to achieve by going "smart"?

Partaking in smart city branding initiatives then becomes a marketing exercise where sales determine the definition of the concept at the moment. De Leeuw (2012) suggested, "Where no-one is quite sure what a smart city is, there is an opportunity to both mystify and 
renegotiate the concept of 'smart' by giving it a new, unique name, that echoes everything you think 'smart' must mean". It is questionable whether isolated smart projects bring sufficient value without a bigger, more comprehensive smart city strategy in place.

\section{Risks}

Plenty of difficulties arise from the fact that many of the demands of a (smart) city are not necessarily mutually compatible (Goswami, 2015). Last but not least, the smart city carries with it inherent security and privacy concerns due to the nature of digital technology, involvement from various stakeholders, and risks of privatization of municipal government (Karl, 2015). "The "Smart City" isn't a technology concept; it's the political challenge of adapting one of the most powerful economic and social forces of our time to the needs of the places where most of us live and work" (Robinson, 2015).

Sadiku et al. (2016) stated, "Building smart cities has its potential barriers and challenges. Smart cities around the world are diverse in their characteristics. Standards (such as established by ISO and IEEE) can play a crucial role in the development of smart cities. We must ensure that the information is secure and the people are secure. Since networks are believed to be the least secure parts of the system, cities must ensure that the networks are safe before embarking on smart city initiatives. Everyone is needed online and needs to be able to access services in order to realize the full benefits of IoT"'

Goswami (2015) warned, "In the absence of a clear definition of the characteristics and its targeted goals, development of smart cities may become more of an exercise of selling and marketing." The basic needs of the majority of the urban centres around the world stand in striking juxtaposition of the smart city innovations that the wealthiest and most advanced cities are deploying. (Zegras, 2015). Robinson (2016) claimed that the inconsistent and contradictory 
definitions (in terms of smart infrastructure or smart citizens, but rarely both) create confusion and prevent acceptance, involvement and support. 


\section{CHAPTER FIVE: SUMMARY, CONCLUSIONS, AND RECOMMENDATIONS}

The smart city narrative is broad, complex, and multi-disciplinary. It offers an opportunity for inclusive solving of pressing urban problems through partnerships with academic institutions, business organizations, individual citizens, etc. Definitions are bent through the individual prism not only of the organization involved, but also of each member, since they are largely open to interpretation. The smart city is a more of a process rather than an end goal, continuously evolving and transforming. The Smart City brand boosts prestige and attractiveness of a city, consequently making the smart city market a lucrative industry segment with huge potential for growth.

Building a smart city (from the ground up or through innovative projects) is really more of a process than a static goal. Cities around the world have lined up behind the "smart city" brand in an effort to attract people and increase their prestige rating, along the way opening up opportunities for businesses and individual citizens to contribute to solving pressing urban challenges. Cities present their own definitions of a smart city that fit their situations and goals. Therefore, it is important to be cautious when comparing smart cities, and perhaps talk about a city becoming "smarter". Because of a lacking standardized and universally-accepted definition, "smart city" has become an umbrella term, often a buzzword, possibly even a marketing tactic that banks on the appeal of ubiquitous technology and promises for a better life. 


\title{
Proposing a New Definition
}

After studying numerous smart city definitions that were either too narrow or too broad, too long or too short, too specific or too generic, the author has created her own definition for "smart city":

\author{
A Smart City is citizen-centric, has useful real-time knowledge of \\ itself, proactively and creatively resolves challenges, and evolves \\ continuously through gradual innovations in all of its \\ characteristics towards definite and measurable goals.
}

First and foremost a city must be focused on serving, facilitating, and engaging with its short-term and long-term inhabitants. To be smart, a city needs to be self-aware and to know what is happening in each of its parameters in real-time. To be smarter than itself or any other city, a city needs to be able to resolve its issues (i.e. infrastructure, environmental impact, etc.) ahead of time through the use of technology and data analysis, for example. "To creatively resolve challenges" means that a smart city employs a variety of resources to combat its problems, including but not limited to digital technology. "Evolves continuously" describes smart city as a process rather than a static destination, and "through gradual innovations" means that changes happen in an incremental, constructive, easier to adopt and digest way, rather than through enormous leaps. "In all of its characteristics" refers to living, economy, people, governance, mobility, and environment.

A truly smart city must innovate in each of these areas in a comprehensive, holistic way, instead of through isolated smart projects. The last part of the definition addresses what needs to be foundation of any smart city strategic plan - the end goals that a smart city aims to accomplish. Without clear, understood, and measurable targets towards which a city strives to 
move, any other initiatives are threatened to fail. According to the author of this paper all of these components must be present and active in order to deem a city smart. 


\section{Appendix A: Smart City Definitions by Cities}

Tokyo, Japan: "Smart city" relates to revolution and environment, meaning a city where technological revolution promotes better living and protects the environment to improve lives of Tokyo’s people."

Singapore: "A Smart Nation is one where people are empowered by technology to lead meaningful and fulfilled lives. Through harnessing the power of networks, data[,] and info-comm technologies, we seek to improve living, create economic opportunity and build a closer community. A Smart Nation is built not by Government, but by all of us - citizens, companies, agencies."

Hong Kong, China: “Objectives of developing Hong Kong into a smart city are: (a) making use of innovation and technology to address urban challenges to enhance city management and improve quality of living, sustainability, efficiency and safety of our city; (b) enhancing city attractiveness to global business and talents; and (c) inspiring continuous city innovation and sustainable economic development."

Beijing, China: "The Smart City: This is the kind of city which features full integration between the application of a new round of scientific and technological innovations such as the Internet of Things, cloud computing[,] and wireless mobile communication on the one hand and the economic and social development on the other; the intelligence, greenness and efficiency in the city operation, personal life, industrial development and administrative management; and the inheritance and innovation of the city culture. It is a new type of city with closely knitted science and technology, culture and social science." 
Dubai, United Arab Emirates: “Collaborating with [the] private sector and government partners, Smart Dubai was established to empower, deliver and promote an efficient, seamless, safe and impactful city experience for residents and visitors."

Sydney, Australia: “[...] rapid development in technology has opened new opportunities to enhance the liveability and therefore the competitiveness of cities - the "smart city"."

Melbourne, Australia: "Our vision for Melbourne as a smart city is simple: to enhance the aspects of our city that make us uniquely Melbourne, and intelligently prepare for the changing needs of the community, the environment[,] and the economy."

New Zealand: "A smart city uses information and communications technology (ICT) to enhance its liveability, workability[,] and sustainability."

London, UK: "A Smart City is a city that uses new forms of information and communications technology (ICT) to promote economic development, civic innovation, the sharing of data, and a high quality of life. Making the city more livable, functional, and competitive, smart cities promote innovation and data sharing to help improve a city's economy, mobility, environment, citizenship, quality of life, and city governance. Smart City infrastructure will also assist in improved decision[-]making through more advanced analytics of data."

Berlin, Germany: "The Smart City approach aims to find solutions to the ecological, social, economic and cultural challenges faced by Berlin through the use of intelligent technology."

Amsterdam, the Netherlands: "A city is smart when investments in capital and communication infrastructure fuel sustainable economic growth and a high quality of life, in combination with an efficient use of natural resources." 
Zürich, Switzerland: "smart cities" in which infrastructures and people are networked digitally".

Vienna, Austria: "[...] the concept of the "smart city", a city that is fit for the future and geared towards opportunities and that is capable of producing credible perspectives for its people. First and foremost we want to secure and further improve its ecological, economic and social performance."

Munich, Germany: "The term "smart city" is often equated with future-oriented urban development. But there is no clear definition. A "smart city" includes a variety of components - it combines city planning with technology, research, social and business. Frequently, the three pillars of sustainability (economics, ecology[,] and social issues) are developed, which in turn are complemented by a technological component. More and more, however, cities define the term "Smart City" individually and tailor-made for themselves as a city. A major challenge is the mediation of the subject matter and the concepts in the population. At the same time, a good cooperation and communication with the city society is a topic of the "Smart City"."

Oslo, Norway: "The vision for Oslo is to make it a smarter, greener, more inclusive and creative city for all citizens - a smart city that innovates with the citizens' interest and well-being at the core."

Copenhagen, Denmark: "The smart city Copenhagen is a living laboratory for testing smart technologies to handle the challenges of urbanisation and climate change. Unique access to data and efficient public-private sector partnerships attract many multinationals."

Madrid, Spain: "the concept of "smart city" where the agents involved can take advantage of the capacity of the information technologies and of the communications deployed for a better management of the resources". 
Helsinki, Finland: "Smart Cities deliver the goods to the citizens via innovative energy, traffic and waste management solutions - among other things. In the age of IoT, there is no telling how far and how high Smart Cities can go.”

Stuttgart, Germany: ,[...] a city is smart if it systematically tries to achieve the objectives of sustainability with the help of new technology. Sound ecology, economic prosperity[,] and social justice do not come automatically. They are the outcome of an intelligent transformation."

Toronto, Canada: "[...] smart city is innovation city".

New York City, USA: "smart city" is an equitable city [...] Equity means we ensure that every New Yorker has equal access to opportunities to reach his or her full potential and to succeed."

Washington, D.C., USA: "Smart city technology leverages intelligent city infrastructure, including connected devices, sensors, and data analytics, to improve [the] quality of life for residents, enhance economic growth, and address city challenges."

Montreal, Canada: "SimpliCity - citizen involvement to test concepts, exchange ideas, react to proposals"

Baltimore, USA: "The Baltimore Smart City Vision focuses on transforming disconnected communities with smart city solutions throughout the city, and the action starts with connecting low-income communities in West Baltimore to economic opportunities while attracting businesses and jobs back to this community."

Dallas, USA: "Our Vision for Smart Dallas is to leverage technology in becoming an inclusive, connected and efficient city focused on improving the quality of life of our citizens. The Smart Domains enable better planning, managing and governing of cities in a sustainable way by maximizing economic opportunities and minimizing environmental damage." 
Buenos Aires, Argentina: "Those cities that have succeeded in implementing successful initiatives capable of transforming the quality of life of its inhabitants in a sustainable, creative and innovative way, taking into account economic, social and environmental aspects" 


\section{Appendix B: Smart City Definitions from the Public Sector}

Fritz Kuhn, the Mayor of the City of Stuttgart in Germany, explains, "What it is all about is the intelligent networking of municipal infrastructures with the aim of achieving a high level of energy and resource efficiency. [...] "Smart City Stuttgart" also means for us using modern information technology for a better civic participation.“(Stuttgart website, n.d.).

Government of Canada states, "A smart city uses technology and data to improve livability and opportunities for the city and its people." Also, "Smart cities have the potential to improve every aspect of community life - how people move around, how they live and play, how they earn a living, how they learn and are empowered to participate in society, how they interact with the natural environment, and how they create safe and secure public spaces." (Infrastructure Canada, n.d.).

The UK Department for Business, Innovation and Skills (BIS) considers smart cities a process rather than a static outcome, in which increased citizen engagement, hard infrastructure, social capital and digital technologies make cities more liveable, resilient and better able to respond to challenges (Centre for Cities, 2014).

According to the Manchester Digital Development Agency, “a 'smart city' means 'smart citizens' - where citizens have all the information they need to make informed choices about their lifestyle, work[,] and travel options" (Centre for Cities, 2014).

European Initiative on Smart Cities says that smart cities focus on energy efficiency and reduction of carbon emissions to improve quality of life and local economies (SETIS, n.d.). 
„A smart city offers its inhabitants maximal life quality with minimal consumption of resources, based on an intelligent interconnection of infrastructure (transport, energy, communication etc.)" (Smart City Switzerland, n.d.).

"The conceptualisation of Smart City, therefore, varies from city to city and country to country, depending on the level of development, willingness to change and reform, resources and aspirations of the city residents. A smart city would have a different connotation in India than, say, Europe. Even in India, there is no one way of defining a smart city." (Ministry of Housing and Urban Affairs, Government of India, n.d.). 


\section{Appendix C: Smart City Definitions from the Private Sector}

IBM defines a smart city as "one that makes optimal use of all the interconnected information available today to better understand and control its operations and optimize the use of limited resources" (Centre for Cities, 2014).

Cisco view cities as smart if they adopt "scalable solutions that take advantage of information and communications technology (ICT) to increase efficiencies, reduce costs, and enhance quality of life" (Centre for Cities, 2014).

International Urban Development Association relates "smartness" to the ability to learn, adapt and innovate (Marzloff \& Sudarskis, 2012).

"A smart sustainable city is an innovative city that uses information and communication technologies (ICTs) and other means to improve quality of life, efficiency of urban operation and services, and competitiveness[] while ensuring that it meets the needs of present and future generations with respect to economic, social, environmental as well as cultural aspects”. (ITU, n.d.)

Smart Cities Council says, "The smart city sector is still in the "I know it when I see it" phase, without a universally agreed definition. The Council defines a smart city as one that has digital technology embedded across all city functions“.

International Telecommunications Union defines, "smart and sustainable cities are innovative cities that use ICT to improve quality of life[] and promote efficient administration, urban services[,] and competitiveness, while meeting the economic, social and environmental needs of current and future generations". Smart cities are built by combining IT with the various 
"bricks" of the city (energy, transport, building, etc.)." ITU-T, Smart Sustainable Cities at a Glance. (n.d.) 


\section{Appendix D: Smart City Definitions in the Media}

Robinson (2015) argues that "it's pretty much impossible to create any concise definition without missing out something important."

CNBC explains smart city in a video as one that uses technology in every aspect, including public transportation, IT connectivity, water, power supply, sanitation, solid waste management, urban mobility, e-governance, and citizen participation (What is a smart city? CNBC Explains).

“The smart city's friendly relationship with ICT systems is turning these greener projects into a technocratic mecca of uber-efficiency and meticulous monitoring. The coming of retrofitting our grey cityscapes into sustainable, ICT friendly metropolis' may be turning into a commercial opportunity, further complicating the politics of the term 'smart' [...] Companies are using the city as a neoliberal space for experiment, and their smartness as the emblem of the city of tomorrow" (de Leeuw, 2012).

"[...] Smart cities use information and communication technologies (ICT) to be more intelligent and efficient in the use of resources, resulting in cost and energy savings, improved service delivery and quality of life, and reduced environmental footprint-all supporting innovation and the low-carbon economy. (Cohen, 2012).

"A Smart City systematically creates and encourages innovations in city systems that are enabled by technology; that change the relationships between the creation of economic and social value and the consumption of resources[,] and that contribute to achieving a vision and clear objectives that are supported by a broad and active collaboration amongst city stakeholders.” (Robinson, 2015). 


\section{REFERENCE LIST}

Abdoullaev, A. (2011). A Smart World: A Development Model for Intelligent Cities. Retrieved from http://www.cs.ucy.ac.cy/CIT2011/files/SMARTWORLD.pdf

Albino, Berardi, \& Dangelico (2015). Smart Cities: Definitions, Dimensions, Performance, and Initiatives. Retrieved from

https://www.researchgate.net/publication/267038770_Smart_Cities_Definitions_Dimensions_Per formance and Initiatives

Amsterdam City Official Website. http://wikiprogress.org/data/organization/amsterdam-smartcity

B. Cohen. (2012, January 11) The Top 10 Smart Cities On The Planet. Retrieved from_ https://www.fastcodesign.com/1679127/the-top-10-smart-cities-on-the-planet

B. Marzloff \& M. Sudarskis. (2012). Smart City. International Urban Development Association_ https://inta-aivn.org/en/activities/exchange/roundtables/2012-paris-smart-city

Baltimore City Official Website. https://cms.dot.gov/sites/dot.gov/files/docs/MD

\%20Baltimore.pdf

Beijing City Official Website.http://www.ebeijing.gov.cn/Government/reports/t1304097.htm

Berlin_City Official Website.

http://www.stadtentwicklung.berlin.de/planen/foren initiativen/smart-

city/download/Strategie_Smart_City_Berlin_en.pdf 
Branchi, P., Matias, I. \& Fernandez-Valdivielso, C. (2014). Analysis Matrix for Smart Cities. Retrieved from

https://www.researchgate.net/publication/276037448_Analysis_Matrix_for_Smart_Cities

Buenos Aires City Official Website. http://www.buenosaires.gob.ar/noticias/plan-microcentrofinalista-de-world-smart-cities-awards

Centre for Cities. (2014) What is a Smart City? Retrieved from http://www.centreforcities.org/reader/smart-cities/what-is-a-smart-city/

Cities for Citizens: towards more human-centered smartness. Smart City Expo World Congress 2016 Report. Retrieved from http://media.firabcn.es/content/S078017/SCEWC2016 Report.pdf

Cities in Motion http://citiesinmotion.iese.edu/indicecim/?lang=en

Copenhagen City Official Website. http://www.copcap.com/set-up-a-business/key-sectors/smart$\underline{\text { city }}$

D. Crane. (2017, May 16). Toronto smart city revolution requires partnerships. Retrieved from_ http://www.itworldcanada.com/article/toronto-smart-city-revolution-requirespartnerships/393206

Dallas City Official Website. http://www3.dallascityhall.com/smart-cities/

Dubai, Smart.http://www.smartdubai.ae/about.php

Glasmeier, A. \& Christopherson, S. (2015). Thinking About Smart Cities. Cambridge Journal of Regions, Economy and Society, 8, 3-12. Retrieved from 
https://dusp.mit.edu/sites/dusp.mit.edu/files/attachments/publications/Smart\%20Cities

\%20CJRES\%20021415.pdf

Goswami, P. (2015). Matrix for a Smart City. Retrieved from

http://www.currentscience.ac.in/Volumes/109/02/0245.pdf

Hong Kong City Official Website.https://www.smartcity.gov.hk/blueprint

I. James. (2016, October 14). Songdo: No Man's City. Retrieved from_-

https://koreaexpose.com/songdo-no-mans-city/

IEEE Core Smart City_http://smartcities.ieee.org/core-cities.html

Infrastructure Canada (n.d.). Smart Cities Challenge. Retrieved from

http://www.infrastructure.gc.ca/plan/cities-villes-eng.html

ITU-T, Smart Sustainable Cities at a Glance. (n.d.). Retrieved from http://www.itu.int/en/ITUT/ssc/Pages/info-ssc.aspx

K. Bird. (2015, November 13). Happy cities for happy people. Retrieved from https://www.iso.org/news/2015/11/Ref2021.html

Kalasatama and the Evolution of the Smart City, (n.d.) Retrieved from https://fiksukalasatama.fi/en/smart-city/blueprint-for-tomorrow/

Land Information New Zealand, Smart Cities Strategic Assessment, 2016 [Smart Cities Strategic Assessment v1.0]. Retrieved from http://www.linz.govt.nz/about-linz/what-weredoing/projects/smart-cities 
London City Official Website. https://www.london.ca/business/Planning-Development/currenttopics/Pages/Future-City.aspx

M. Lazarte. (2015, October 5). How to measure the performance of smart cities. Retrieved from_ https://www.iso.org/news/2015/10/Ref2001.html

Madrid City Official Website.

http://www.madrid.es/portales/munimadrid/es/Inicio/Actualidad/Noticias/Madrid-impulsa-sumodelo-Smart-City? vgnextfmt=default\&vgnextoid=a5d4ca08566a1410 VgnVCM1000000b205a0aRCRD\&vgnextch annel=a12149fa40ec9410 VgnVCM100000171f5a0aRCRD

Melbourne City Official Website.http://www.melbourne.vic.gov.au/about-melbourne/melbourneprofile/smart-city/Pages/smart-city.aspx

Ministry of Housing and Urban Affairs, Government of India, (n.d.). What is Smart City? Retrieved from http://smartcities.gov.in/content/innerpage/what-is-smart-city.php

Montreal City Official Website.https://simplicite.montreal.ca/en/about

Munich_City Official Website. https://www.muenchen.de/rathaus/Stadtverwaltung/Referat-fuerStadtplanung-und-Bauordnung/Stadtentwicklung/Perspektive-Muenchen/Smart-City.html

N. Ahmed-Ullah (2015, May 8). U of T's Patricia McCarney launches Open City Data Portal. Retrieved from https://www.utoronto.ca/news/u-ts-patricia-mccarney-launches-open-city-dataportal 
New York City Official Website. https://www1.nyc.gov/site/forward/innovations/smartnyc.page

O. de Leeuw (2012). Cities In Competition: Branding The Smart City. Retrieved from http://tedx.amsterdam/2012/09/cities-in-competition-branding-the-smart-city/

Oslo City Official Website.https://www.oslo.kommune.no/english/politics-andadministration/smart-oslo/

R. Pringle. (2017, May 20). Google plans to 'fix' Toronto by building smart city. Retrieved from_ http://www.cbc.ca/news/technology/google-smart-city-toronto-1.4123289

R. Robinson. (2015, February 15).6 inconvenient truths about Smart Cities. Retrieved from https://theurbantechnologist.com/2015/02/15/6-inconvenient-truths-about-smart-cities/

R. Robinson. (2016, February 1). Why Smart Cities still aren't working for us after 20 years. And how we can fix them. Retrieved from https://theurbantechnologist.com/category/smarter-cities/

S. Guzmán. (2015). Pathway for Smart Sustainable Cities: A guide for city leaders. Retrieved from http://itunews.itu.int/en/6276-A-guide-for-city-leaders.note.aspx

S. Karl (2015, March 23). Thinking About Smart Cities. Retrieved from_ https://uwaterloo.ca/stratford-campus/blog/post/thinking-about-smart-cities

Sadiku, M., Shadare, A., Dada, E. \& Musa, S. (2016). Smart Cities: Aspects to Consider for Building a Model from a City Government Point of View [Abstract]. International Journal of Scientific Engineering and Applied Science, 2(10). Retrieved from https://www.researchgate.net/publication/309204708_Smart_Cities 
SETIS European Initiative on Smart Cities (n.d.). https://setis.ec.europa.eu/set-planimplementation/technology-roadmaps/european-initiative-smart-cities

Singapore Official Website.https://www.smartnation.sg/

Smart Cities Council. (n.d.). http://smartcitiescouncil.com/smart-cities-informationcenter/definitions-and-overviews

Smart City Switzerland. (n.d.).http://www.smartcity-suisse.ch/en/smart-city/

Songdo International Business District. (n.d.). Retrieved August 13, 2017 from the Songdo Wiki: https://en.wikipedia.org/wiki/Songdo_International_Business_District

Stockholm the Connected City (n.d.). Retrieved from http://www.stokab.se/Documents/Nyheter \%20bilagor/Stokab_eng.pdf

Stuttgart City Official Website.http://www.stuttgart.de/img/mdb/publ/27286/122129.pdf

Sydney City Official Website.http://www.sydneyyoursay.com.au/digital-strategy

Tokyo City Official Website. http://www.seisakukikaku.metro.tokyo.jp/GFCT/english/pdf/290519/08hgijirokuen.pdf

United Nations. World Population Prospects: The 2017 Revision. P.7 p.18. Retrieved from https://esa.un.org/unpd/wpp/Publications/Files/WPP2017_KeyFindings.pdf

United Nations. World Urbanization Prospects: 2014 Revision.p.23. Retrieved from_ https://esa.un.org/unpd/wup/Publications/Files/WUP2014-Report.pdf 
Vienna City Official Website.https://smartcity.wien.gv.at/site/en/the-initiative/

Washington D.C. City Official Website.https://smarter.dc.gov/AboutUs.aspx

What is a smart city? CNBC Explains. [Video file]. Retrieved from

https://www.youtube.com/watch?v=bANfnYDTzxE

Zegras, C., Eros, E., Butts, K., Resor, E., Kennedy, S., Ching, A., Mamum, M. (2015) Tracing a path to knowledge? Indicative user impacts of introducing a public transport map in Dhaka, Bangladesh, Cambridge Journal of Regions, Economy and Society, 8: 113-129.

Zurich City Official Website. https://www.stadt-

zuerich.ch/hbd/de/index/ueber_das_departement/medien/medienmitteilungen/2016/november/16

1123a.html 